\title{
Another oral antiviral treatment, but still far away from hepatitis B virus cure
}

\author{
Tai-Chung Tseng ${ }^{1,2,3}$ \\ ${ }^{1}$ Division of Gastroenterology and Hepatology, Department of Internal Medicine, National Taiwan University Hospital, Taipei; ${ }^{2}$ Hepatitis \\ Research Center, National Taiwan University Hospital, Taipei; ${ }^{3}$ Department of Medical Research, National Taiwan University Hospital, \\ Taipei, Taiwan
}

Keywords: Hepatitis B virus; Besifovir dipivoxil maleate; Hepatitis B surface antigens; Hepatitis B, Chronic

\section{See Article on Page 346}

Chronic hepatitis B virus (HBV) infection continues to be a crucial health issue worldwide as more than 200 million individuals are positive for hepatitis B surface antigen (HBsAg). ${ }^{1}$ Patients with chronic HBV infection are at an increased risk of developing liver cirrhosis and hepatocellular carcinoma (HCC), resulting in over one million deaths per year. ${ }^{2}$ So far, there is no cure for HBV and prolonged suppression of viral replication via inhibiting reverse transcriptase by nucleos(t)ide analogue (NA) treatment is the only way to minimize their liver-related complications and to reduce HCC risk. ${ }^{2}$

Three potent NAs, including tenofovir disoproxil fumarate (TDF), tenofovir alafenamide, and entecavir, are recommended as firstline treatment by clinical practice guidelines. Besifovir dipivoxil maleate (BSV) is a new acyclic nucleotide phosphonate with potent antiviral activity against HBV., In this study, Song et al. ${ }^{5}$ explored BSV's antiviral efficacy and drug safety up to 192 weeks in two groups: 170 patients continuing BSV treatment (BSV-BSV) and 152 patients switching from TDF to BSV after 48 weeks (TDFBSV). They found more than $90 \%$ of virological response rates over 192 weeks in both groups and no drug-resistant mutations to BSV. Bone mineral density and renal function were well preserved in the BSV-BSV group, whereas these initially worsened then recovered after switching therapy in the TDF-BSV group. However, only one participant achieved HBsAg loss in both groups. $^{5}$

Prolonged NA treatment to suppress viral replication is the mainstay treatment strategy in current practice. According to this study, 4-year viral suppression is still far from achieving HBsAg clearance, ${ }^{5}$ which is also compatible with other clinical studies using different NA treatments. ${ }^{6,7}$ In addition to the on-going clinical trials aiming at $\mathrm{HBsAg}$ clearance, ${ }^{8}$ there are several issues that need to be addressed. First, as the goal for prolonged NA treatment is to reduce HCC risk, a precise HCC prediction model in addition to serum HBV DNA and alanine aminotransferase levels is mandatory to decide who should receive early antiviral treatment. ${ }^{9}$ For example, around $50 \%$ of HBeAg-negative patient without liver cirrhosis are in grey zone for antiviral treatment and

\section{Abbreviations:}

BSV, besifovir dipivoxil maleate; HBsAg, hepatitis B surface antigen; $\mathrm{HBV}$, hepatitis $B$ virus; HCC, hepatocellular carcinoma; NA, nucleos(t)ide analogue; TDF, tenofovir disoproxil fumarate

\section{Corresponding author : Tai-Chung Tseng}

Division of Gastroenterology, Department of Internal Medicine, National Taiwan University Hospital, 1 Chang-Te St., Taipei 10002, Taiwan

Tel: +886-2-23123456 ext. 66613, Fax: +886-2-23825962

E-mail: tctsenghbv@gmail.com

https://orcid.org/0000-0003-0420-8311 
their prognosis is heterogenous. ${ }^{10-12}$ With a better prediction model integrated with more viral markers, ${ }^{13,14}$ we may be able to identify some of the grey-zone patients who need early antiviral treatment due to the elevated HCC risk.

The second issue is how to predict the residual HCC risk after prolonged antiviral treatment to minimize viral replication. In addition to host factors, including age and sex, ${ }_{1}^{15}$ surrogate markers for liver fibrosis have shown their potential to improve the prediction performance of current $\mathrm{HCC}$ prediction models. ${ }^{16,17}$ A better HCC prediction model may impact how to perform cost-effective surveillance for HCC.

In summary, although BSV provides us another NA choice to suppress viral replication activity, it is still far from achieving HBsAg clearance. The current unmet need for physicians is to identify the patients with high $\mathrm{HCC}$ risk for an early antiviral treatment and to define the residual $\mathrm{HCC}$ risk after long-term antiviral treatment, which may impact the $\mathrm{HCC}$ surveillance system.

\section{Conflicts of Interest}

T-C. T. has served on speaker's bureaus for Bristol-Myers Squibb and Gilead Sciences and received research grant from Gilead Sciences.

\section{REFERENCES}

1. Schweitzer A, Horn J, Mikolajczyk RT, Krause G, Ott JJ. Estimations of worldwide prevalence of chronic hepatitis $B$ virus infection: a systematic review of data published between 1965 and 2013. Lancet 2015;386:1546-1555.

2. Tseng TC, Kao JH. Elimination of hepatitis b: is it a mission possible? BMC Med 2017;15:53.

3. Yim HJ, Kim W, Ahn SH, Yang JM, Jang JY, Kweon YO, et al. Besifovir dipivoxil maleate 144-week treatment of chronic hepatitis B: an open-label extensional study of a phase 3 trial. Am J Gastroenterol 2020;115:1217-1225.

4. Ahn SH, Kim W, Jung YK, Yang JM, Jang JY, Kweon YO, et al. Efficacy and safety of besifovir dipivoxil maleate compared with tenofovir disoproxil fumarate in treatment of chronic hepatitis B virus infection. Clin Gastroenterol Hepatol 2019;17:1850-1859.e4.

5. Song DS, Kim W, Ahn SH, Yim HJ, Jang JY, Kweon YO, et al. Continuing besifovir dipivoxil maleate versus switching from tenofovir disoproxil fumarate for treatment of chronic hepatitis $B$ : results of 192-week phase 3 trial. Clin Mol Hepatol 2021;27:346-359.
6. Buti M, Gane E, Seto WK, Chan HL, Chuang WL, Stepanova T, et al. Tenofovir alafenamide versus tenofovir disoproxil fumarate for the treatment of patients with $\mathrm{HBeAg-negative} \mathrm{chronic} \mathrm{hepatitis} \mathrm{B} \mathrm{virus}$ infection: a randomised, double-blind, phase 3, non-inferiority trial. Lancet Gastroenterol Hepatol 2016;1:196-206.

7. Marcellin P, Gane E, Buti M, Afdhal N, Sievert W, Jacobson IM, et al. Regression of cirrhosis during treatment with tenofovir disoproxil fumarate for chronic hepatitis B: a 5-year open-label follow-up study. Lancet 2013;381:468-475.

8. Revill PA, Chisari FV, Block JM, Dandri M, Gehring AJ, Guo H, et al. A global scientific strategy to cure hepatitis B. Lancet Gastroenterol Hepatol 2019;4:545-558.

9. Inoue T, Tanaka Y. Novel biomarkers for the management of chronic hepatitis B. Clin Mol Hepatol 2020;26:261-279.

10. Di Bisceglie AM, Lombardero $M$, Teckman J, Roberts L, Janssen $H L$, Belle $\mathrm{SH}$, et al. Determination of hepatitis B phenotype using biochemical and serological markers. J Viral Hepat 2017;24:320-329.

11. Bonacci $M$, Lens $S$, Mariño Z, Londoño MC, Rodríguez-Tajes S, Mas $A$, et al. Anti-viral therapy can be delayed or avoided in a significant proportion of HBeAg-negative Caucasian patients in the grey zone. Aliment Pharmacol Ther 2018;47:1397-1408.

12. Lee HW, Kim SU, Baatarkhuu O, Park JY, Kim DY, Ahn SH, et al. Progression of untreated minimally active chronic HBV infection compared to inactive infection. Clin Gastroenterol Hepatol 2019;17:2808-2810.e2.

13. Tseng TC, Liu CJ, Yang HC, Su TH, Wang CC, Chen CL, et al. High levels of hepatitis $B$ surface antigen increase risk of hepatocellular carcinoma in patients with low HBV load. Gastroenterology 2012;142:1140-1149.e3; quiz e13-e14.

14. Tseng TC, Liu CJ, Hsu CY, Hong CM, Su TH, Yang WT, et al. High level of hepatitis $B$ core-related antigen associated with increased risk of hepatocellular carcinoma in patients with chronic HBV infection of intermediate viral load. Gastroenterology 2019;157:15181529.e3.

15. Papatheodoridis G, Dalekos G, Sypsa V, Yurdaydin C, Buti M, Goulis J, et al. PAGE-B predicts the risk of developing hepatocellular carcinoma in Caucasians with chronic hepatitis B on 5-year antiviral therapy. J Hepatol 2016;64:800-806.

16. Tseng TC, Peng CY, Hsu YC, Su TH, Wang CC, Liu CJ, et al. Baseline Mac-2 binding protein glycosylation isomer level stratifies risks of hepatocellular carcinoma in chronic hepatitis B patients with oral antiviral therapy. Liver Cancer 2020;9:207-220.

17. Tseng TC, Choi J, Nguyen MH, Peng CY, Siakavellas S, Papatheodoridis $\mathrm{G}$, et al. One-year fibrosis-4 index helps identify minimal HCC risk in non-cirrhotic chronic hepatitis B patients with antiviral treatment. Hepatol Int 2021;15:105-113. 